\begin{tabular}{|c|c|c|c|c|c|c|}
\hline \multirow{4}{*}{ Impact Factor: } & ISRA (India) & $=3.117$ & SIS (USA) & $=0.912$ & ICV (Poland) & $=6.630$ \\
\hline & ISI (Dubai, UAE & $=0.829$ & РИНЦ (Russia & $=0.156$ & PIF (India) & $=1.940$ \\
\hline & GIF (Australia) & $=0.564$ & ESJI (KZ) & $=8.716$ & IBI (India) & $=4.260$ \\
\hline & JIF & $=1.500$ & SJIF (Morocco & $=5.667$ & OAJI (USA) & $=0.350$ \\
\hline
\end{tabular}

\section{SOI: $1.1 /$ TAS $\quad$ DOI: $10.15863 /$ TAS \\ International Scientific Journal Theoretical \& Applied Science}

\author{
p-ISSN: 2308-4944 (print) e-ISSN: 2409-0085 (online) \\ Year: 2019 Issue: $08 \quad$ Volume: 76
}

Published: 19.08.2019 http://T-Science.org
QR - Issue

QR - Article
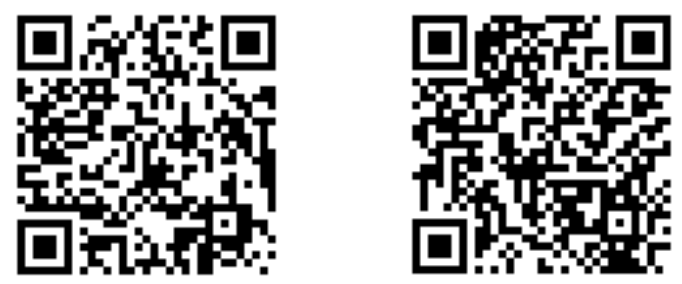

Oleg Ivanovych Yurchenko

Kharkiv V.N. Karazin National University, PhD, Full Professor of Chemical Metrology Department, yurchenko@karazin.ua

Tetyana Vasylivna Chernozhuk Kharkiv V.N. Karazin National University, $\mathrm{PhD}$, Associate Professor of Inorganic Chemistry Department, tanya.chernozhuk@gmail.com

Oleksii Andriovych Kravchenko Kharkiv V.N. Karazin National University, $\mathrm{PhD}$, Associate Professor of Chemical Metrology Department, alekseykravch@ukr.net

\title{
ATTESTATION OF THE TEST SAMPLE OF SODIUM CEFAZOLIN FOR THE DETERMINATION OF THE ACCOMPANYING IMPURITIES BY THE METHOD OF LIQUID CHROMATOGRAPHY IN INTERLABORATORY COMPARATIVE TEST
}

\begin{abstract}
Certification of a test sample of cefazolin sodium was performed to determine the accompanying impurities in the professional testing program. The adscripted value of the content of the accompanying impurities in the test sample of cefazolin sodium was obtained and the homogeneity of the test sample of cefazolin sodium in the content of the accompanying impurities was confirmed. It is established that the number of accompanying impurities meets the requirements of the State Pharmacopoeia of Ukraine (SPhU). The suitability parameters of the chromatographic system meet the requirements of SPhU. It is established that the test sample is homogeneous.

All the questions regarding the professional testing program, the use of liquid chromatography are represented in $\quad[1, p .17 ; 2, p .4 ; 3, p .1 ; 4, p .34 ; 5, p .19 ; 6, p .1090 ; 7, p .7 ; 8, p .2 ; 9, p .1 ; 10, p .93 ; 11, p .36 ; 12, p .12 ; 13, p .350 ; 14, p .235 ; 15$, p.262;16,p.13; 17,p.7;18,p.343;19,p.35;20,p.16;21,p.65;22,p.59;23,p.55,24,p.137;25,p.36].

Key words: professional testing program, test sample, certification, high effective liquid chromatography, suitability check of the chromatographic system.

Language: English

Citation: Yurchenko, O. I., Chernozhuk, T. V., \& Kravchenko, O. A. (2019). Attestation of the test sample of sodium cefazolin for the determination of the accompanying impurities by the method of liquid chromatography in interlaboratory comparative test. ISJ Theoretical \& Applied Science, 08 (76), 130-137.
\end{abstract}

Soi: http://s-o-i.org/1.1/TAS-08-76-19 Doi: crossef https://dx.doi.org/10.15863/TAS.2019.08.76.19

Classifiers: Chemistry and chemical technology.

Introduction

The main purpose of this work was to test the test sample of cefazolin sodium, to determine the attributable value of the number of accompanying impurities in the test sample of cefazolin sodium, to study the homogeneity and stability of the test sample of cefazolin sodium and the validation of the verification test of the suitability of the chromatographic system.

\section{Experimental part}

The object of attestation

The object for attestation in terms of TR (technical report) for the determination of the 


\begin{tabular}{|c|c|c|c|c|c|c|}
\hline \multirow{4}{*}{ Impact Factor: } & ISRA (India) & $=3.117$ & SIS (USA) & $=0.912$ & ICV (Poland) & $=6.630$ \\
\hline & ISI (Dubai, UAI & $=0.829$ & РИНЦ (Russia & $=0.156$ & PIF (India) & $=1.940$ \\
\hline & GIF (Australia) & $=0.564$ & ESJI (KZ) & $=8.716$ & IBI (India) & $=4.260$ \\
\hline & JIF & $=1.500$ & SJIF (Morocce & $=5.667$ & OAJI (USA) & $=0.350$ \\
\hline
\end{tabular}

accompanying impurities by HPLC method in PTS (production technical service) was selected medicine "Cefazolin for injection", which according to the monograph of HFC [24], is a sterile powder of cephazolin sodium, placed in a hermetically sealed container.<smiles>Cc1nnc(SCC2=C(C(=O)O[Na])N3C(=O)[C@@H](NC(=O)Cn4cnnn4)[C@H]3SC2)s1</smiles>

Cephazolin sodium is a semi-synthetic antibiotic from the first generation of cephalosporins.

\section{Properties}

Description: crystalline powder of white or almost white color, very hygroscopic.

Solubility: Easily soluble in water P, very low soluble in $96 \%$ alcohol $\mathrm{P}$.

\section{Impurities}

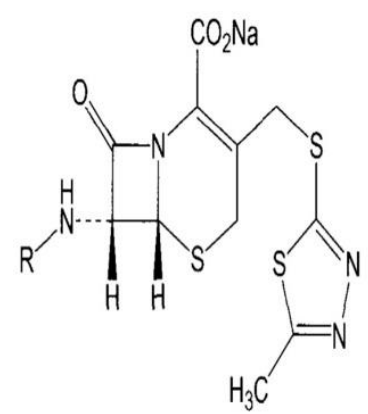

A. $\mathrm{R}=\mathrm{H}:(6 \mathrm{R}, 7 \mathrm{R})-7$ - amino - 3 [[[5 - methyl - 1,3,4 - thiadiazol - 2 - yl] sulfonyl] methyl] - 8 - oxo - 5 - thia - 1 - azabicyclo [4.2.0] oct - 2 - en - 2 carboxylic acid

B. $\mathrm{R}=\mathrm{CO}-\mathrm{C}(\mathrm{CH} 3)$ 3: $(6 \mathrm{R}, 7 \mathrm{R})-7-[(2,2-$ dimethylpropanoyl) amino] - 3 - [[5 - methyl - 1,3,4 thiadiazol - 2 - yl] ) sulfonyl] methyl] - 8 - oxo - 5 thia - 1 - azabicyclo [4.2.0] oct - 2 - en - 2 - carboxylic acid<smiles>[R]CC1=C(C(N)=O)N2C[C@@H](SC1)[C@@H](NC(=O)Cn1cnnn1)C2=O</smiles>

C. $\mathrm{R}=\mathrm{H}:(6 \mathrm{R}, 7 \mathrm{R})-3-$ methyl -8 - oxo -7 [(1H - tetrazole - 1 - ylacetyl $)$ amino $]-5$ - thia - 1 azabicyclo [4.2.0] oct - 2 - en - 2 - carboxylic acid
D. R = O-CO-CH3: (6R, 7R) -3 - [(acetyloxy) methyl $]-8$ - oxo - 7 - [(1H - tetrazole - 1 - ylacetyl $)$ amino] - 5 - thia - 1 - azabicyclo [4.2.0] oct - 2 - en 2 - carboxylic acid<smiles>Cc1nnc(S)s1</smiles>
(MMTD)

E. 5 - methyl - 1,3,4 - thiadiazole - 2 - thiol<smiles>O=C(Cn1cnnn1)N[C@H]1C(=O)N2C3=C(COC3=O)CS[C@H]12</smiles>

G. $(5 \mathrm{a}, \mathrm{R}, 6 \mathrm{R})-6-[(1 \mathrm{H}-$ tetrazole $-1-1$ ylacetyl) amino] - 5a, 6 - dihydro - $3 \mathrm{H}, 7 \mathrm{H}$ - azeto [(2,1 - b] furo [3, 4 - d] [1,3] thiazine - 1,7 $(4 \mathrm{H})$ - dione.<smiles>CC(=O)OCC1=C(C(=O)O)N2C(=O)[C@@H](N)[C@H]2SC1</smiles>

H. (6R, 7R) -3 - [(acetyloxy) methyl] - 7 - amino - 8 - oxo - 5 - thia - azaabicyclo [4.2.0] oct - 2 - en - 2 - carboxylic acid (7ACA)<smiles>Cc1nnc(SCC(CSC(NC(=O)Cn2cnnn2)C(=O)O)C(=O)O)s1</smiles>

I. 2 - [carboxy [(1H - tetrazole - 1 - 1 - ylacetyl $)$ amino] methyl] - 5 [[5 - methyl - 1,3,4 - thiadiazol - 2 - yl) sulfanyl] methyl] - 5,6 - dihydro - 2H - 1,3 thiazine - 4 - carboxylic acid (cefazolinic acid) 


\begin{tabular}{|c|c|c|c|c|c|c|}
\hline \multirow{4}{*}{ Impact Factor: } & ISRA (India) & $=3.117$ & SIS (USA) & $=0.912$ & ICV (Poland) & $=6.630$ \\
\hline & ISI (Dubai, UAI & $=0.829$ & РИНЦ (Russia & $=0.156$ & PIF (India) & $=1.940$ \\
\hline & GIF (Australia) & $=0.564$ & ESJI (KZ) & $=8.716$ & IBI (India) & $=4.260$ \\
\hline & JIF & $=1.500$ & SJIF (Morocce & $=5.667$ & OAJI (USA) & $=0.350$ \\
\hline
\end{tabular}<smiles>O=C(Cn1cnnn1)NC(=C1N=C(C(O)O)C(CO)CS1)C(O)O</smiles>

J. 2 - [carboxy [(1H - tetrazole - 1 - 1 - ylacetyl) amino] methyl] - 5 -) hydroxymethyl) - 5,6 - dihydro - 2H - 1,3 - thiazine - 4 - carboxylic acid (hydrolyzed cefazolinic) acid)

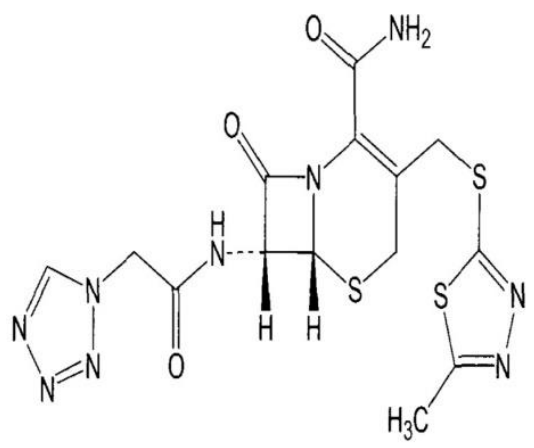

K. (6R, 7R) -3 - [[5 - methyl - 1,3,4 - thiadiazol - 2 - yl) sulfanyl $]$ methyl $]$ - 8 - oxo - 7 - [(1H - tetrazole - 1 - 1 - ylacetyl) ) amino] - 5 - thia - 1 - azoabicyclo [4.2.0] octo - 2 - en - 2 - carboxamide (cefazolinamide)

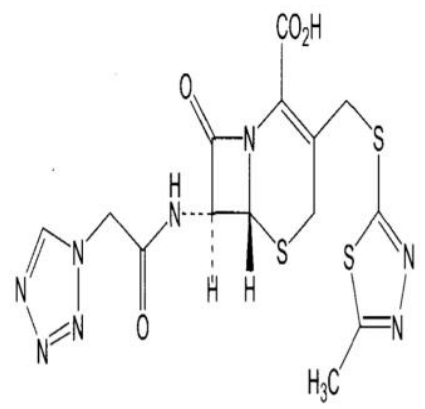

L. $(6 \mathrm{R}, 7 \mathrm{~S})$-3 - [[5 - methyl - 1,3,4 - thiadiazol 2 - yl) sulfanyl $]$ methyl $]-8$ - oxo - 7 - [(1H - tetrazole - 1 - 1 - ylacetyl) ) amino] - 5 - thia - 1 - azoabicyclo [4.2.0] oct - 2 - en - 2 - carboxylic acid [24,p.100].

Moreover, the medicine "Cefazolin for injection" must meet the requirements of the article of SPhU "Medicines for parenteral use", additionally tov the section "Powders for injectable or infusion drugs".

Criteria for attestation of TR

In order to achieve the aim of this work, we determined the content of the accompanying impurities in the five test samples of the drug "Cefazolin powder for solution for injection". In this way we estimated the content of the accompanying impurities in the TR with acceptable uncertainty and confirmed the homogeneity of the TR with the content of the accompanying impurities.

The criterion for the permissible uncertainty of the impurity content as a result of the attestation $\left(\Delta_{\mathrm{RS}}\right)$ is its insignificance compared to the permissible uncertainty of the determination method $\left(\Delta_{\mathrm{An}}\right)$. The same criterion can be applied to the assessment of the uniformity of the TR.

$\Delta_{\mathrm{RS}} \leq 0,32 \cdot \Delta_{\mathrm{An}}$, so $\Delta_{\mathrm{RS}} \leq 0,51 \%$

Thus, it should be noticed that another important parameter is the stability of the TR during the time of testing. This parameter was studied in previous experiments and determined as to be acceptable, but the conclusion will be reached after the end of the beginning testing. Therefore, this parameter is not the object of study of this work.

\section{Results and discussions}

\subsection{Research of TR certification}

The tests are carried out according to the methodology of the "Accompanying Impurities" indicator in SPhU "Cefazolin Injection Monograph" [24], following the general State Pharmacopoeia of Ukraine article 2.2.29 "Liquid Chromatography" [25].

Experiment technique. Preparation of the test solution: A quantity of the mixed contents of 10 containers was dissolved in mobile phase A to obtain a solution with a concentration of $2.5 \mathrm{mg} / \mathrm{ml}$ cefazolin.

Preparation of comparison solution (a): $1.0 \mathrm{ml}$ of the test solution was adjusted to a volume of $100.0 \mathrm{ml}$ with mobile phase A.

Preparation of the comparison solution (b): according to Federal Health Care Reference Book (FHC), the preparation of a solution of cefazolin in a solution of $2 \mathrm{~g} / \mathrm{l}$ sodium hydroxide $\mathrm{P}$ with a concentration of $2 \mathrm{mg} / \mathrm{ml}$ cefazolin, infuse from 15 min to $30 \mathrm{~min} .1 .0 \mathrm{ml}$ of the resulting solution was adjusted to $20.0 \mathrm{ml}$ with mobile phase A.

Chromatographic column requirements:

- Size $0.125 \mathrm{~mm} \times 4.0 \mathrm{~mm}$;

- Stationary phase: silica gel for chromatography, octadecylsilyl silicagel, encapsulated P $(3 \mu \mathrm{m})$;

- Temperature: $450^{\circ} \mathrm{C}$.

The mobile phase composition:

- Mobile phase A: solution containing $14.54 \mathrm{~g} / \mathrm{l}$ disodium hydrophosphate $\mathrm{P}$ and $3.53 \mathrm{~g} / 1$ potassium dihydrophosphate $\mathrm{P}$;

- Mobile phase B: acetonitrile for P chromatography;

Speed of the mobile phase: $1.2 \mathrm{ml} / \mathrm{min}$.

Detection: spectrophotometrically at $254 \mathrm{~nm}$.

Injections: $5 \mu \mathrm{l}$.

Applicability of the chromatographic system: comparison solution (b):

- Degree of separation: not less than 2.0 between the peak of cefazolin and the peak with relative retention to cefazolin of about 1.1 . 


\begin{tabular}{|c|c|c|c|c|c|c|}
\hline \multirow{4}{*}{ Impact Factor: } & ISRA (India) & $=3.117$ & SIS (USA) & $=0.912$ & ICV (Poland) & $=6.630$ \\
\hline & ISI (Dubai, UAI & $=0.829$ & РИНЦ (Russia & $=0.156$ & PIF (India) & $=1.940$ \\
\hline & GIF (Australia) & $=0.564$ & ESJI (KZ) & $=8.716$ & IBI (India) & $=4.260$ \\
\hline & JIF & $=1.500$ & SJIF (Morocce & $=5.667$ & OAJI (USA) & $=0.350$ \\
\hline
\end{tabular}

Normalization:

- Any impurity: on the chromatogram of the test solution, the area of any peak other than the main one must not exceed the area of the main peak on the chromatograph of the comparison solution (a) (1.0\%);

- The number of impurities: on the chromatogram of the test solution, the sum of the areas of all peaks except the main one should not exceed 3.5 the area of the main peak on the chromatogram of the comparison solution (a) (3.5\%);

- Exclude peaks which area is less than 0.05 of the area of the main peak in the chromatogram of the comparison solution (a) $(0.05 \%)$.

Calculation formula:

$$
\mathrm{X}=\left(\mathrm{S}_{1} * 1.0\right) / \mathrm{S}_{0}
$$

where

- S1 is the area of the impurity peak on the chromatogram of the test solution;

- S0 is the peak area of cefazolin in the chromatogram of the comparison solution (a).

The methodology of the "Compound impurity" indicator in "Cefazolin for Injection" monograph of SPhU [24] regulates only one parameter of checking the suitability of the chromatographic system (CSCS), determined from the chromatogram of the comparison solution (b): the degree of separation: not less than 2.0 between the peak of cefazolin and peak with a relative retention to cephazolin of about 1.1 .

However, following the requirements of the general article of SPhU «2.2.29. Liquid chromatography" [25], for the tests for the content of the impurities, the peak symmetry coefficient and the limit of quantification (LQC) must be monitored.

Thus, CSCS for determination of the accompanying impurities of cefazolin was performed according to the following parameters: the degree of separation (from the chromatogram of the comparison solution (b)) and the symmetry coefficient of the peak and the limit of quantitative determination (from the chromatogram of the comparison solution (a)).

CSCS parameters were calculated following the general article "2.2.46. Chromatographic separation methods » of SPhU [17]. The degree of separation and the peak symmetry coefficient are calculated using the chromatography software.

LQC is calculated, given that the concentration of cefazolin in the solution of comparison (a) is $1.0 \%$, by the formula:

$$
\mathrm{LQC}=\frac{1.0 \cdot 10}{\mathrm{~S} / \mathrm{N}}
$$

It should be ensured that, according to the pharmacopeia requirements [17], the LQC should be no greater than the disregarded limit. According to the methodology of the Cefazolin Injection Monograph [24], the unaccounted limit is $0.05 \%$, that is, the LQC calculated should be no more than $0.05 \%$.

\subsubsection{Experimenting TR certification}

The medicine "Cephazolin powder for solution for injection", $1.0 \mathrm{~g}$ produced by a Ukrainian pharmaceutical company was certified as a test sample for the determination of the accompanying impurities.

Mobile Phase A: $3.53 \mathrm{~g}$ of potassium dihydrophosphate $\mathrm{P}$ add to $14.54 \mathrm{~g}$ of disodium hydrophosphate $\mathrm{P}$, dissolve in $700 \mathrm{ml}$ of water $\mathrm{P}$ and bring the volume of the solution with water $\mathrm{P}$ to $1000.0 \mathrm{ml}$

Mobile phase B: acetonitrile for $\mathrm{P}$ chromatography

Preparation of solutions:

Test solution: $130.0 \mathrm{mg}$ of the substance was dissolved in mobile phase $\mathrm{A}$ and the volume of the solution was adjusted to $50.0 \mathrm{ml}$ with the same solvent.

Comparison solution (a): Adjust $1.0 \mathrm{ml}$ of the test solution to $100.0 \mathrm{ml}$ with mobile phase A.

Comparison solution (b): $21 \mathrm{mg}$ of FHC cefazolin was dissolved in a solution of $2 \mathrm{~g} / 1$ sodium hydroxide $\mathrm{P}$ and the volume of the solution was adjusted to $10.0 \mathrm{ml}$ with the same solvent. The resulting solution was maintained for 15 to 30 minutes. $1.0 \mathrm{ml}$ of the resulting solution was adjusted to $20.0 \mathrm{ml}$ with mobile phase A.

Verification of the suitability of the chromatographic system:

The degree of separation (Rs) between the peaks of Cefazolin and its impurities L on the chromatogram of the comparison solution $b$ is 3.1 , which satisfies the requirements of the Cefazolin Injection Monograph [24], not less than 2.0.

The chromatography of the comparison solution $\mathrm{b}$ is represented in the Appendix.

CSCS:

the symmetry coefficient is within the range specified in HFC - from 0.8 to 1.5 ;

LQC does not exceed the unaccounted for limit $0.05 \%$.

\section{Conclusions}

- The suitability of the chromatographic system was investigated and their stability and compliance with the specified requirements were confirmed. 


\begin{tabular}{llllll} 
& ISRA (India) $=\mathbf{3 . 1 1 7}$ & SIS (USA) $=\mathbf{0 . 9 1 2}$ & ICV (Poland) & $=\mathbf{6 . 6 3 0}$ \\
Impact Factor: & ISI (Dubai, UAE) $=\mathbf{0 . 8 2 9}$ & PUHL (Russia) $=\mathbf{0 . 1 5 6}$ & PIF (India) & $=\mathbf{1 . 9 4 0}$ \\
& GIF (Australia) $=\mathbf{0 . 5 6 4}$ & ESJI (KZ) $=\mathbf{8 . 7 1 6}$ & IBI (India) & $=\mathbf{4 . 2 6 0}$ \\
& JIF & $\mathbf{1 . 5 0 0}$ & SJIF (Morocco) $=\mathbf{5 . 6 6 7}$ & OAJI (USA) & $\mathbf{0 . 3 5 0}$ \\
\hline
\end{tabular}

Table 1. Gradient of the mobile phase

\begin{tabular}{|l|l|l|}
\hline Time (min.) & Mobile phase A (\%) & Mobile phase B (\%) \\
\hline $0-2$ & 98 & 2 \\
\hline $2-4$ & $98 \rightarrow 85$ & $2 \rightarrow 15$ \\
\hline $4-10$ & $85 \rightarrow 60$ & $15 \rightarrow 40$ \\
\hline $10-11.5$ & $60 \rightarrow 35$ & $40 \rightarrow 65$ \\
\hline $11.5-12$ & 35 & 65 \\
\hline $12-15$ & $35 \rightarrow 98$ & $65 \rightarrow 2$ \\
\hline $15-21$ & 98 & 2 \\
\hline
\end{tabular}

Table 2. Experiment technique

\begin{tabular}{|l|l|l|l|l|}
\hline № & Name of the device & Type of & Data \\
\hline 1. & Analytic scales & $\begin{array}{l}\text { Scales ES 225M-DR, } \\
\text { by“PreisaGravimetrics” } \\
\text { checking }\end{array}$ & 07.11 .2017 & Automatic \\
\hline 2. & $\begin{array}{l}\text { Chromatographic } \\
\text { column }\end{array}$ & $\begin{array}{l}\text { Waters Aliance 2690 } \\
\text { КолонкаSymmetryShield } \\
\text { RP18, 4,6*100 } \\
3,5 \mathrm{mkm} 3 \mu \mathrm{m}, \text { Waters }\end{array}$ & 10.11 .2017 & According to COP qualification \\
& & & \\
\hline
\end{tabular}

Table 3. Masses of samples

\begin{tabular}{|l|l|}
\hline Name of the sample & Mass of the sample, $\mathrm{mg}$ \\
\hline Test 1 & 0.1300 \\
\hline Test2 & 0.1288 \\
\hline Test3 & 0.1293 \\
\hline Test4 & 0.1300 \\
\hline Test5 & 0.1301 \\
\hline
\end{tabular}

Table 4. The results of solution A chromatography

\begin{tabular}{|l|l|l|l|l|l|}
\hline Name of solution & Peak square, S & S & RSD, \% & $\begin{array}{l}\text { Symmetry } \\
\text { coefficient }\end{array}$ & MKB, \% \\
\hline \multirow{2}{*}{ ref a } & 129109 & \multirow{2}{*}{128618} & 0.44 & 1.04 & 0,05 \\
\cline { 5 - 6 } & 128753 & & 1.09 & 0,05 \\
\cline { 2 - 4 } & 127992 & & 1.11 & 0,05 \\
\hline
\end{tabular}

Table 5. The results of the sample A determination

\begin{tabular}{|l|l|l|l|l|l|}
\hline Name of sample & $\begin{array}{l}\text { Peak square, } \\
\mathbf{C y}-\mathbf{1 . 3 4}\end{array}$ & $\begin{array}{l}\text { Peak square, } \\
\mathbf{C y}-\mathbf{1 . 7 5}\end{array}$ & $\begin{array}{l}\text { Peak square, } \\
\mathbf{C y}-\mathbf{3 . 4 5}\end{array}$ & $\begin{array}{l}\text { Peak square, } \\
\mathbf{C y}-\mathbf{5 . 1 5}\end{array}$ & $\begin{array}{l}\text { Peak } \\
\mathbf{C y}-\mathbf{5 . 4 0}\end{array}$ \\
\hline \multirow{2}{*}{ Test 1 } & 14320 & 70656 & 18654 & 7880 & 14092 \\
\cline { 2 - 6 } & 13167 & 67961 & 17725 & 8042 & 12363 \\
\hline Average square & 13744 & 69309 & 18190 & 7961 & 13228 \\
\hline $\begin{array}{l}\text { Impurity } \\
\text { contain, \% }\end{array}$ & 0.11 & 0.54 & 0.14 & 0.06 & 0.10 \\
\hline $\begin{array}{l}\text { Sum } \\
\text { impurities, \% }\end{array}$ & 0.95 & & & \\
\hline
\end{tabular}




\begin{tabular}{llllll} 
& ISRA (India) $=\mathbf{3 . 1 1 7}$ & SIS (USA) $=\mathbf{0 . 9 1 2}$ & ICV (Poland) & $=\mathbf{6 . 6 3 0}$ \\
Impact Factor: & ISI (Dubai, UAE) $=\mathbf{0 . 8 2 9}$ & PUHL (Russia) $=\mathbf{0 . 1 5 6}$ & PIF (India) & $=\mathbf{1 . 9 4 0}$ \\
& GIF (Australia) $=\mathbf{0 . 5 6 4}$ & ESJI (KZ) & $=\mathbf{8 . 7 1 6}$ & IBI (India) & $=\mathbf{4 . 2 6 0}$ \\
& JIF & $\mathbf{1 . 5 0 0}$ & SJIF (Morocco) $\mathbf{5 . 6 6 7}$ & OAJI (USA) & $\mathbf{0 . 3 5 0}$ \\
\hline
\end{tabular}

Table 6. The results of the sample 2 determination

\begin{tabular}{|c|c|c|c|c|c|}
\hline $\begin{array}{ll}\begin{array}{l}\text { Name } \\
\text { sample }\end{array} & \text { of } \\
\end{array}$ & $\begin{array}{l}\text { Peak square, } \\
\text { Cy }-1.34\end{array}$ & $\begin{array}{l}\text { Peak square, } \\
\text { Cy }-1.75\end{array}$ & $\begin{array}{l}\text { Peak square, } \\
\text { Cy }-\mathbf{3 . 4 5}\end{array}$ & $\begin{array}{l}\text { Peak square, } \\
\text { Cy }-\mathbf{5 . 1 5}\end{array}$ & $\begin{array}{l}\text { Peak square, Cy } \\
-5.40\end{array}$ \\
\hline \multirow{2}{*}{ Test 2} & 15423 & 73006 & 16410 & 9318 & 11960 \\
\hline & 15423 & 73006 & 16410 & 9318 & 11960 \\
\hline Average square & 15423 & 73006 & 16410 & 9318 & 11960 \\
\hline $\begin{array}{l}\text { Impurity } \\
\text { contain, \% }\end{array}$ & 0.12 & 0.57 & 0.13 & 0.07 & 0.09 \\
\hline $\begin{array}{l}\text { Sum of } \\
\text { impurities, } \%\end{array}$ & \multicolumn{5}{|l|}{0.95} \\
\hline
\end{tabular}

Table 7. The results of the sample 3 determination

\begin{tabular}{|c|c|c|c|c|c|}
\hline $\begin{array}{ll}\text { Name } & \text { of } \\
\text { sample } & \\
\end{array}$ & $\begin{array}{l}\text { Peak square, } \\
\text { Cy }-\mathbf{1 . 3 4}\end{array}$ & $\begin{array}{l}\text { Peak square, } \\
\text { Cy }-1.75\end{array}$ & $\begin{array}{l}\text { Peak square, } \\
\text { Cy - 3.45 }\end{array}$ & $\begin{array}{l}\text { Peak square, } \\
\text { Cy - 5.15 }\end{array}$ & $\begin{array}{l}\text { Peak square, } \\
\text { Cy - 5.40 }\end{array}$ \\
\hline \multirow{2}{*}{ Test 3} & 14729 & 75543 & 18286 & 9101 & 13374 \\
\hline & 13309 & 65242 & 18904 & 7673 & 13821 \\
\hline Average square & 14019 & 70393 & 18595 & 8387 & 13598 \\
\hline $\begin{array}{l}\text { Impurity } \\
\text { contain, } \%\end{array}$ & 0.11 & 0.55 & 0.14 & 0.07 & 0.11 \\
\hline $\begin{array}{l}\text { Sum of } \\
\text { impurities, \% }\end{array}$ & \multicolumn{5}{|l|}{0.97} \\
\hline
\end{tabular}

Table 8. The results of the sample 4 determination

\begin{tabular}{|l|l|l|l|l|l|}
\hline $\begin{array}{l}\text { Name } \\
\text { sample }\end{array}$ & $\begin{array}{l}\text { Peak square, } \\
\mathbf{C y}-\mathbf{1 . 3 4}\end{array}$ & $\begin{array}{l}\text { Peak square, } \\
\mathbf{C y}-\mathbf{1 . 7 5}\end{array}$ & $\begin{array}{l}\text { Peak square, } \\
\mathbf{C y}-\mathbf{3 . 4 5}\end{array}$ & $\begin{array}{l}\text { Peak square, } \\
\mathbf{C y}-\mathbf{5 . 1 5}\end{array}$ & $\begin{array}{l}\text { Peak square, } \\
\mathbf{C y}-\mathbf{5 . 4 0}\end{array}$ \\
\hline \multirow{2}{*}{ Test 4 } & 16213 & 79134 & 16511 & 10005 & 9929 \\
\cline { 2 - 6 } & 13900 & 68546 & 18755 & 7939 & 13759 \\
\hline Average square & 15057 & 73840 & 17633 & 8972 & 11844 \\
\hline $\begin{array}{l}\text { Impurity } \\
\text { contain, \% }\end{array}$ & 0.12 & 0.57 & 0.14 & 0.07 & 0.09 \\
\hline $\begin{array}{l}\text { Sum of } \\
\text { impurities, \% }\end{array}$ & 0.99 & & & \\
\hline
\end{tabular}




\begin{tabular}{llllll} 
& ISRA (India) $=\mathbf{3 . 1 1 7}$ & SIS (USA) $=\mathbf{0 . 9 1 2}$ & ICV (Poland) & $=\mathbf{6 . 6 3 0}$ \\
Impact Factor: & ISI (Dubai, UAE) $=\mathbf{0 . 8 2 9}$ & PUHL (Russia) $=\mathbf{0 . 1 5 6}$ & PIF (India) & $=\mathbf{1 . 9 4 0}$ \\
& GIF (Australia) $=\mathbf{0 . 5 6 4}$ & ESJI (KZ) $=\mathbf{8 . 7 1 6}$ & IBI (India) & $=\mathbf{4 . 2 6 0}$ \\
& JIF & $\mathbf{1 . 5 0 0}$ & SJIF (Morocco) $=\mathbf{5 . 6 6 7}$ & OAJI (USA) & $\mathbf{0 . 3 5 0}$ \\
\hline
\end{tabular}

Table 9. The results of the sample 5 determination

\begin{tabular}{|l|l|l|l|l|l|}
\hline $\begin{array}{l}\text { Name } \\
\text { sample }\end{array}$ & $\begin{array}{l}\text { Peak square, } \\
\mathbf{C y}-\mathbf{1 . 3 4}\end{array}$ & $\begin{array}{l}\text { Peak square, } \\
\mathbf{C y}-\mathbf{1 . 7 5}\end{array}$ & $\begin{array}{l}\text { Peak square, } \\
\mathbf{C y}-\mathbf{3 . 4 5}\end{array}$ & $\begin{array}{l}\text { Peak square, } \\
\mathbf{C y}-\mathbf{5 . 1 5}\end{array}$ & $\begin{array}{l}\text { Peak square, } \\
\mathbf{C y}-\mathbf{5 . 4 0}\end{array}$ \\
\hline \multirow{2}{*}{ Test 5 } & 15163 & 79243 & 16067 & 9375 & 13102 \\
\cline { 2 - 6 } & 13215 & 70408 & 17276 & 8932 & 13247 \\
\hline Average square & 14189 & 74826 & 16672 & 9154 & 13175 \\
\hline $\begin{array}{l}\text { Impurity } \\
\text { contain, \% }\end{array}$ & 0.11 & 0.58 & 0.13 & 0.07 & 0.10 \\
\hline $\begin{array}{l}\text { Sum } \\
\text { impurities, \% }\end{array}$ & 1.00 & & & \\
\hline
\end{tabular}

Table 10. The results of the tests samples homogeneity

\begin{tabular}{|l|l|l|l|l|l|l|}
\hline № of the sample & $\begin{array}{l}\text { Contain of } \\
\text { impurity } 1,\end{array}$ & $\begin{array}{l}\text { Contain of } \\
\text { impurity } \\
2, \%\end{array}$ & $\begin{array}{l}\text { Contain of } \\
\text { impurity 3, } \\
\%\end{array}$ & $\begin{array}{l}\text { Contain of } \\
\text { impurity 4, } \\
\%\end{array}$ & $\begin{array}{l}\text { Contain of } \\
\text { impurity 5, } \\
\%\end{array}$ & Sum of impurities, \% \\
\hline 1 & 0.11 & 0.54 & 0.14 & 0.06 & 0.10 & 0.95 \\
\hline 2 & 0.12 & 0.57 & 0.13 & 0.07 & 0.09 & 0.98 \\
\hline 3 & 0.11 & 0.55 & 0.14 & 0.07 & 0.11 & 0.97 \\
\hline 4 & 0.12 & 0.57 & 0.14 & 0.07 & 0.09 & 0.99 \\
\hline 5 & 0.11 & 0.58 & 0.13 & 0.07 & 0.10 & 1.00 \\
\hline Average & $\mathbf{0 . 1 1}$ & $\mathbf{0 . 5 6}$ & $\mathbf{0 . 1 4}$ & $\mathbf{0 . 0 7}$ & $\mathbf{0 . 1 0}$ & $\mathbf{0 . 9 8}$ \\
\hline SD & 0.006 & 0.018 & 0.007 & 0.004 & 0.006 & 0.019 \\
\hline$\Delta_{\text {imp }}=\left(\mathrm{SD}^{*}\right.$ t) $\%$ & $\mathbf{0 . 0 1 2}$ & $\mathbf{0 . 0 3 9}$ & $\mathbf{0 . 0 1 6}$ & $\mathbf{0 . 0 0 9}$ & $\mathbf{0 . 0 1 3}$ & $\mathbf{0 . 0 4 1}$ \\
\hline Requirements to $\Delta_{\text {imp }} \%$ & $\mathbf{0 . 5 1}$ &
\end{tabular}

\section{References:}

1. Leontev, D. A. (2007). Farmakom. V.2 .pp $16-$ 25.

2. (2010). ISO/IEC 17043:2010(E), Conformity assessment. General requirements for proficiency testing, Geneva

3. (2007). DSTU ISO/IEC 17025:2006 «Zagalni vimogi do kompetentnosti doslidnih ta kalibruvalnih laboratorij», Kiïv: Derzhspozhivstandart Ukraïni.

4. Dmitrieva, M.V. ( 2012). Farmakom. V. 1/2. pp. $33-38$.

5. Sur, S. V. (2011). Programi profesijnogo testuvannja jak zasib standartizaciï roboti laboratorï z kontrolju jakosti likars'kih zasobiv $U$ kn. [Harkiv: vidavnictvo «NTMT», 2011, pp. $3-1064$.
6. Leontev, D. A. (2011). Farmacevtichni standartni zrazki. Harkiv: vidavnictvo «NTMT», pp. $1085-1104$

7. (2010). ST - N MOZU 42-4.0:2011. - Likarski zasobi. Nalezhna virobnicha praktika Kï̈v, MOZ Ukraïni, p.281.

8. (n.d.). ICH Topic Q10. - Pharmaceutical Quality System.

9. (n.d.). The Rules Governing Medecinal Products in the Europian Union. Volume 3A: Quality Guidelines. - Guideline 3AQ11a: Specifications and Control Tests on the Finished Products.

10. (2008). Validacija analitichnih metodik i viprobuvan' : Derzhavna Farmakopeja Ukraïni. pp. $85-100$. 


\begin{tabular}{llllll} 
& ISRA (India) $=\mathbf{3 . 1 1 7}$ & SIS (USA) $=\mathbf{0 . 9 1 2}$ & ICV (Poland) & $\mathbf{= 6 . 6 3 0}$ \\
Impact Factor: & ISI (Dubai, UAE) $=\mathbf{0 . 8 2 9}$ & PUHL (Russia) $=\mathbf{0 . 1 5 6}$ & PIF (India) & $=\mathbf{1 . 9 4 0}$ \\
& GIF (Australia) $=\mathbf{0 . 5 6 4}$ & ESJI (KZ) $=\mathbf{8 . 7 1 6}$ & IBI (India) & $\mathbf{4 . 2 6 0}$ \\
& JIF & $\mathbf{1 . 5 0 0}$ & SJIF (Morocco) $=\mathbf{5 . 6 6 7}$ & OAJI (USA) & $\mathbf{0 . 3 5 0}$ \\
\hline
\end{tabular}

11. Grizodub, A. I. (2006). Farmakom. V.2 .pp $35-$ 44.

12. Orlov, V. I., \& Aratskov, A. A. (1997). Ridinna hromatografija. Teoretichni osnovi. Dzerzhins'k, Naukovo - tehnologichna kompanija «Sinetko», p.14.

13. Bekker, J. (2009). Hromatogrfija. Instrumental'na analitika: metodi hromatografii ta kapiljarnogo elektroforezu. (p.473). Moscow: Tehnosfera.

14. Sichov, K. S. (2010). Praktichne kerivnictvo $z$ ridinnoï hromatografiï. (p.272). Moscow: Tehnosfera.

15. Sadek, P.S. (1999). Jak uniknuti pomilok u visokoefektivnij ridinnij hromatografii. (p.435). Kiïv: Alsi.

16. Shatc, V. D., \& Sahartova, O. V. (1988). Visokoefektivna ridinna hromatografija: Osnovi teorii. Metodologija. Zastosuvannja u likars'kij himii. (pp.11-21). Riga: Zinatne.

17. (2015). Metodi hromatografichnogo rozdilennja : Derzhavna Farmakopeja Ukraïni «Naukovo ekspertnij farmakopejnij centr», $126 \mathrm{pp}$.
18. Kylner, R. (2004). Analitichna himija. Problemi ta pidhodi. (p.730). Moscow: Mir.

19. Epshtejn, N. A. (2002). Ocinka mezhi kilkisnogo viznachennja $z$ urahuvannjam vimog do vidtvorjuvanosti rezul'tativ analizu, OFO «Himfarmkombinat «Akrihin», Stara Kupavna Moskovs'koï oblasti, p.52.

20. Henke, H. (2010). Ridinna hromatografija. (pp.20-22). Moscow: Tehnosfera.

21. Jashin, J.I., \& Jashin, A.J. (2003). Visokoefektivna ridinna hromatografija. Stan ta perspektivi. Rosijs'kij himichnij zhurnal, pp.6466.

22. Ghulam, A. (2003). Journal of Chromatography. V.987, pp.57-66.

23. Sangeetha, M., \& Rubina, R. C. (2014). Joutnal of Pharmaceutical Analysis, pp.50 - 56.

24. (2015). "Cefazolin natriju» : Derzhavna Farmakopeja Ukraïni. Derzhavne pidpriemstvo «Naukovo - ekspertnij farmakopejnij centr, p.575.

25. (2015). Ridinna hromatografija: Derzhavna Farmakopeja Ukraïni, p.86. 